\title{
NEW YEAR'S MESSAGE ON FORESTRY
}

\author{
Honourable T. A. Crerar \\ Minister of the Interior
}

\section{$\prod$}

HERE IS every reason to anticipate improved conditions during the coming year in the great basic industries dependent on the forest resources of the Dominion. During the past year the production of pulp and paper has practically equalled in volume that of 1929 which marked the peak of production in that industry. During the first ten months of this year the exports of newsprint have been greater than in the same period in any year since 1930. The increasing amount of construction as evidenced by the building permits issucd and the contracts awarded indicate that a considerable improvement in the domestic demand for lumber is to be expected.

The renewed activity in logging reflects a confidence in the increasing demand for forest products, it being estimated that about 125,000 men are so employed this winter.

The number of cars loaded on Canadian railways with forest products is also indicative of increased trade, the number during the first forty-eight weeks of this year being 330,510 as against 252,923 in 1933 .

\section{EXPORT TRADE}

Canada is normally dependent on foreign markets for the disposal of about two-fifths of all the wood cut. Prior to the economic depression (192630 ) the value of these exports averaged $\$ 278,500,719$ annually, of which 87 per cent went to the United States. Export trade was reduced to $\$ 130$,785,302 in 1933 , but increased to $\$ 160,039,612$ in 1934 . In the latter year the exports to the United States amounted to only $\$ 107,473,462$, or 67 per cent of the total. Though it is not to be expected that this trade will resume pre-depression volume until conditions improve in that country, the recently concluded trade agreement with the United States will remove to a large extent the handicap to which Canadian exporters have been subjected.

Though the exports of lumber to the United States are of great importance to the Canadian industry, they represent a very small proportion of the amount used in that country. I am glad to note in this connection that the National Lumber Manufacturers Association of the U. S. has withdrawn its opposition to the agreement.

The improvement in the trade in forest products during the last three years has been due primarily to increased exports to the United Kingdom 
REPORT OF SILVICULTURAL SUB-COMMITTEE

and other British countries. This applies particularly to lumber, but also to a relatively smaller extent to pulp and paper.

In the European countries with which Canada must compete in the markets of the world, forestry and manufacturing are highly developed on a scientific basis. In these countries the growing of timber is considered a matter of national importance, and stringent laws govern the management of woodlands, with the result that they are able to produce from limited areas a continuous supply of timber to support their industries. To meet this competition, Canadian industries must not only manufacture products of a superior quality, but they must meet the prices quoted by manufacturers in those countries. The Forest Service of the Department of the Interior is assisting in solving the manufacturing problems by research conducted in the Forest Products Laboratories located in Ottawa, Montreal and Vancouver.

One of the large elements in the cost of wood products is the cost of the raw material. Heretofore Canadian industries have had little difficulty in securing wood supplies from the virgin forests along the streams flowing down to the mills. Now, however, the more accessible timber has been cut and to a large extent destroyed by fire, so that serious local shortages have developed and more remote areas which are more expensive to operate have had to be tapped. Fortunately the forests have been re-established over a large proportion of the cut-over and burned-over areas, and if protected and properly cared for, these young forests can be made to yield more timber of the desired kinds than the original stands. In order to determine the extent and nature of the natural reproduction, and the length of time it will take to produce merchantable stands, the Forest Service has been conducting extensive surveys in typical areas. The Service has also established permanent forest experiment stations in Alberta, Manitoba, Ontario, Quebec and New Brunswick where silvicultural studies and experiments in cultural methods applicable to the various types of forest are being conducted.

If we are to continue as a major producer of wood products, we must seeto it that our forests are not destroyed by fire and that our more accessible areas, at least, are kept in a state of maximum production. The co-operation of the provinces and woods operators is essential to progress in this direction, and it is a matter for great satisfaction that at the Conference on Forest Research recently held in Ottawa, the various interests were so unanimous in their support of the efforts of the Department of the Interior in promoting forest research. 